Article

\title{
Comparative Physicochemical and Microbiological Qualities of Source and Stored Household Waters in Some Selected Communities in Southwestern Nigeria
}

\author{
Mary A. Bisi-Johnson ${ }^{1, *}$, Kehinde A. Adediran ${ }^{1}$, Saheed A. Akinola ${ }^{1}$, Elizabeth O. Popoola ${ }^{2}$ and \\ Anthony I. Okoh ${ }^{3}$ \\ 1 Department of Microbiology, Obafemi Awolowo University, Ile-Ife, Nigeria; \\ bumic2012@gmail.com (K.A.A.); seddorf2003@yahoo.com (S.A.A.) \\ 2 Department of Chemical Science, Yaba College of Technology, Lagos, Nigeria; \\ oluseun.popoola@yabatech.edu.ng \\ 3 SAMRC Microbial Water Quality Monitoring Centre, University of Fort Hare, Alice, South Africa; \\ aokoh@ufh.co.za \\ * Correspondence: jumokade@yahoo.co.uk or jumokade@oauife.edu.ng; Tel.: +2348134443245
}

\begin{abstract}
In this study, we evaluated the physicochemical and microbial qualities of source and stored household waters in some communities in Southwestern Nigeria using standard methods. Compared parameters include physicochemical constituents; Temperature (T), $\mathrm{pH}$, Total Dissolved Solids (TDS), Total Hardness (TH), Biological Oxygen Demand (BOD), Magnesium ion $\left(\mathrm{Mg}^{2+}\right)$ and Calcium ion $\left(\mathrm{Ca}^{2+}\right)$ and microbiological parameters included Total Coliform Counts (TC), Faecal Coliform Counts (FC), Fungal Counts (Fung C), Heterotrophic Plate Counts (HPC). Comparing Stored and Source samples, the mean values of some physicochemical parameters of most of the stored water samples significantly $(\mathrm{P}<0.05)$ exceeded that of Sources and ranged in the following order: $\mathrm{T}\left(15.3 \pm 0.3^{\circ} \mathrm{C}-28.3 \pm 0.5^{\circ} \mathrm{C}\right), \mathrm{pH}(6.4 \pm 0.1-7.6 \pm 0.1)$, TDS $(192.1 \pm 11.1 \mathrm{ppm}-473.7 \pm 27.9 \mathrm{ppm}), \mathrm{TH}$ $(10.6 \pm 1.7 \mathrm{mg} / \mathrm{L}-248.6 \pm 18.6 \mathrm{mg} / \mathrm{L}), \mathrm{BOD}(0.5 \pm 0.0 \mathrm{mg} / \mathrm{L}-3.2 \pm 0.3 \mathrm{mg} / \mathrm{L}), \mathrm{Mg}^{2+}(6.5 \pm 2.4 \mathrm{mg} / \mathrm{L}-29.1 \pm 3.2$ $\mathrm{mg} / \mathrm{L})$ and $\mathrm{Ca}^{2+}(6.5 \pm 2.4 \mathrm{mg} / \mathrm{L}-51.6 \pm 4.4 \mathrm{mg} / \mathrm{L})$. The mean microbial counts obtained from microbial comparison of different points (Stored and Source) of collection showed that most of the stored water had counts significantly exceeding $(\mathrm{P}<0.05)$ those of the source water samples $(\mathrm{cfu} / 100 \mathrm{~mL})$ which ranged as follows: TC $(3.1 \pm 1.5$ - 156.8 \pm 42.9$)$, FC $(0.0 \pm 0.0$ - 64.3 \pm 14.2$)$ and HPC $(47.8 \pm 12.1$ $266.1 \pm 12.2)$ across all sampled communities. Also, the predominant isolates recovered from the samples were identified as Escherichia coli, Klebsiella pneumonia, Pseudomonas aeruginosa, Enterobacter aerogenes, Aspergillus spp, Mucor spp, Rhizopus spp and Candida spp. The presence of these pathogenic and potentially pathogenic organisms in the waters and the high counts of the indicator organisms suggest the waters to be a threat to public health.
\end{abstract}

Keywords: water; physical; chemical; microbiological; quality; household; stored; source

\section{Introduction}

Increase in development has brought about continuous scarcity of water resources in many parts of the world [1]. In Nigeria, access to safe water and sanitation is a major challenge, $53 \%$ of the populace in rural and $28 \%$ in urban areas have no access to improved water sources [2]. Water Aids Nigeria reported that around 57 million Nigerians lack access to safe potable water while over 130 million people (two thirds of the population) do not have access to adequate sanitation [3]. Water provides essential elements, but when polluted it may become undesirable substance that is dangerous to human health [4]. Water pollution is a main global problem, a leading cause of death and diseases which calls for evaluation and revision of water resources at all levels [5]. The specific contaminants leading to pollution in water include a wide spectrum of chemical, pathogens, physical or sensory changes such as elevated temperature and discoloration [6,7]. The pathogens 
include Salmonella species, Escherichia coli, parasitic worm, virus (hepatitis A), helminthes such as guinea worm [8,9].

Lack of safe drinking water and inadequate sanitation measures introduce diseases causing pathogens such as E. coli, Salmonella species, Vibrio cholera into water. These pathogens can cause water-borne diseases like cholera, typhoid, nausea, cramp and diarrhoea in either human or animal hosts [10]. Water-borne pathogens pose special risk for millions of lives especially infants, young children under the age of five and people with severe compromised immune system [11, 12]. Every year millions of lives are claimed in developing countries and death of more than 2 million people per year worldwide is caused by diarrhoea, mostly among children under the age of five [11,12]. The purity of water depends on its source, treatment received and storage facilities available [13].

Surface and ground waters serve as sources of water for many people; however, these can be contaminated by biological and chemical pollutants arising from point and non-point sources [14]. Farmlands, urban residential subsistence and livestock farming have been shown as some of the effect of human activities on surface water quality [15]. The variations in the water quality were characterized by physicochemical parameters such as $\mathrm{NH}_{4}-\mathrm{N}$, total $\mathrm{N}$, soluble reactive phosphorus, total $\mathrm{P} \mathrm{NO}_{3}-\mathrm{N}$, temperature, $\mathrm{pH}$ and dissolved organic carbon. Hence, anthropogenic pollution influences physical and chemical parameters of water which in turn impact on the distribution and species diversity of biotic life in water bodies $[16,17]$. Also, surface water such as streams, rivers and lakes which are sources of drinking water are mostly untreated and associated with various health risks $[18,19]$. The groundwater is believed to be comparatively much clean and free from pollution than surface water but over exploitation of resources, prolonged discharge of industrial effluents, domestic sewage and solid waste dump causes the groundwater to become polluted and created health problems [20]. Other contaminants find their way into ground through activities of seepage of municipal landfills, and septic tank effluent. Likewise, indiscriminate waste disposal which are becoming serious in many Nigerian cities that lack efficient waste disposal system or treatment plants also contribute to contamination [21]. Availability of water through surface and groundwater resources is becoming critical day to day.

Only $1 \%$ part is available on land for drinking, agriculture, domestic power generation, industrial consummation, transportation and waste disposal [22]. Scarcity in quantity and access to water make storage of water imperative. Domestic storage of water can be made in a cemented reservoir, plastic tanks, bucket or metal tanks, earthen pot [23]. Storage is generally believed to reduce the number of microorganisms in water, nevertheless, several other factors affect microflora of stored water which include sedimentation, activities of other organisms, light ray, temperature and food supply [24].

Furthermore, uncovered containers are exposed to environmental conditions such as dust and dirt which may contribute to the deterioration in water quality [25-27]. Storage containers placed on the floor may be more likely contaminated by animals or children than containers placed on an elevated surface $[28,29]$. Water stored in open-top containers appears more likely to become contaminated by unhygienic vessels than screw-cap closed containers which do not require the use of such vessels [26, 28]. The inability of government at the different tiers to meet the increasing water demand in Nigeria leading to people resorting to the use of untreated or inadequately treated surface and ground water and the need for storing sourced water at the household level with the concomitant health risks necessitated this study. To ensure safe water at the household point of consumption, sources of contaminants have to be verified and prevented [30], hence, this study is aimed at comparing the physicochemical and microbiological qualities of source and stored water in some selected locations in western part of Nigeria.

\section{Materials and Methods}

\subsection{Study Area and Sampling}


Samples of source and stored water were collected from three different States (Osun, Oyo and Lagos). The study area is distributed within four selected local governments (LG) from each state. Lagos, Osun and Oyo states, in Southwest Nigeria are located between longitudes $4^{\circ} 1^{\prime} \mathrm{E}$ and $5^{\circ} 31^{\prime}$ $30^{\prime \prime} \mathrm{E}$ and latitudes $7^{\circ} 12^{\prime} \mathrm{N}$ and $8^{\circ} 32^{\prime} 30^{\prime \prime} \mathrm{N}$. (Figure 1).

One hundred and eighty water samples were collected from 120 houses in four LG each of three states (Lagos: Mushin, Odi-Olowo, Surulere, Yaba; Oyo: Akinyele, Ibadan North, Ibadan North-West, Ibadan South-East and Osun: Ife Central, Ife East, Ife North, Ife South).Water samples both source (well (60), spring (15), borehole (30) and municipal water (15)) and stored (60) were collected in duplicates. Sampling of well water, however, constitutes the major source of drinking water in these areas. Most of the wells were not less than 10 years old, privately owned and are usually open to general public. Half of the numbers of the studied wells were covered while the others were not. Drawing of water from these wells was done by the use of 5-7 L containers, which is tied directly to the well cover. In certain cases where this is not possible, individual fetcher usually comes with small bucket to draw water. Aside from well water, some of the surface waters used as source water are as shown in supplementary material. These are mostly untreated and exposed to debris and contamination through various anthropogenic activities.

Samples were collected aseptically in the morning using the sampling and storage procedures according to [31]. All samples were collected in $1000 \mathrm{~mL}$ sterile sample bottles and immediately transported in cooler boxes from sample sites to the laboratory for analysis within $24 \mathrm{~h}$ [32].

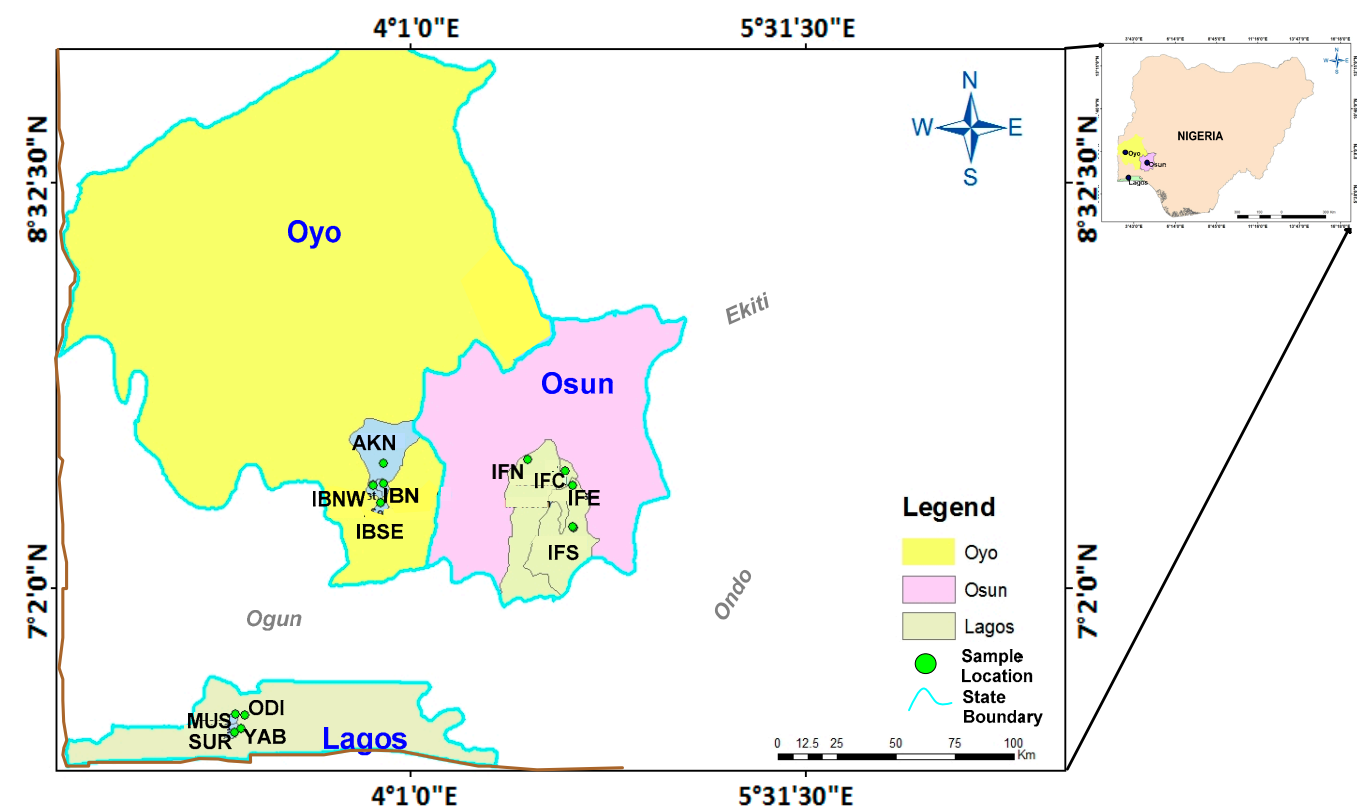

Figure 1: Demographic representation of sampled areas

Key: AKN=Akinyele; IBN=Ibadan North; IBSE=Ibadan South East; IBNW=Ibadan North West; IFC=Ife Central; IFN=Ife North; IFE=Ife East; IFS=Ife South; MUS=Mushin; SUR=Surulere; YAB=Yaba; ODI=Odi-Olowo

\subsection{Physicochemical analyses of collected samples}

The samples were analysed for physical and chemical water quality parameters as described by FAO [33]. The sample temperature, $\mathrm{pH}$ and total dissolved solids (TDS) were determined at the point of sampling using portable hand $\mathrm{pH}$ meter (Hanna instruments, China), mercury thermometer (model 275-k) and digital TDS-meter (Hanna instruments model TDS-02/TDS-03) respectively. Turbidity was also measured at point of collection by measuring the absorbance of the sample at 540 $\mathrm{nm}$ wavelength using colorimeter.

Off-sites parameters: biological oxygen demand BOD and dissolved oxygen (DO) were evaluated using standard titrimetric methods [32]. Calcium and magnesium ion contents were 
analysed using PerkinElmer 400 Atomic Absorption Spectrophotometer at different wavelengths (422.67 nm, and $589.21 \mathrm{~nm}$ respectively) [34]. Total hardness of the water was determined by calculation method described by Ademoroti [35] using this formula: $2.5 \times\left(\mathrm{Ca}^{+} \mathrm{mg} / \mathrm{L}\right)+4.1 \mathrm{x}$ $\left(\mathrm{Mg}^{+} \mathrm{mg} / \mathrm{L}\right)=\ldots \ldots \ldots \ldots \ldots(\mathrm{mgCaCO})$.

\subsection{Microbiological analyses of collected samples}

Total coliform (TC), faecal coliform (FC), faecal enterococci (EC), heterotrophic plate count (HPC) and fungi count of samples were determined using membrane filtration technique [32]. Aliquot of $100 \mathrm{~mL}$ from each sample was filtered through sterile Millipore filter papers (porosity of $0.45 \mu \mathrm{m})$ in a membrane filter apparatus. After filtration, the filter papers were transferred aseptically onto plates containing sterile absorbent pad soaked with different broths (m-Endo broth, m-FC broth with Rosolic acid, m-KF-Streptococcal broth, m-HPC broth and Y. M. green broth respectively.

Plates were incubated in an inverted position for the growth of thermo-tolerant faecal coliforms at $44.5^{\circ} \mathrm{C}$ for $24 \mathrm{~h} \pm 2, \mathrm{TC}, \mathrm{EC}$ and $\mathrm{HPC}$ at $35^{\circ} \mathrm{C}$ for $48 \mathrm{~h}$, and fungi at $20-28^{\circ} \mathrm{C}$ for $5-7$ days [32]. Pure cultures of isolates obtained were subjected to standard morphological and biochemical tests to identify bacterial and fungal isolates respectively [35,36].

\subsection{Statistical Analysis}

Data collected were subjected to One-way analysis of variance (ANOVA) using Statistical Package for Social Sciences [(SPSS) Version 20 software]. Comparison were done to assess whether samples varied significantly between sampling points and point of use or storage, possibilities less than $0.05(\mathrm{p}<0.05)$ were considered statistically

\section{Results}

\subsection{Physicochemical analysis of source and stored samples}

The results of the physicochemical parameters of analyzed samples are shown in Table 1. In Osun state, the mean values of the stored water were higher than the source in all these parameters: $\mathrm{pH}$, temperature, DO, BOD, total hardness except turbidity and TDS. In Oyo and Lagos state, only two parameters ( $\mathrm{DO}$ and $\mathrm{pH}$ ) had higher values for stored water while in other parameters the values for source water were greater than the stored water. The acidity and alkalinity $(\mathrm{pH})$ level of samples ranged between $6.4 \pm 0.2$ to $6.9 \pm 0.1$ (slightly acidic) with the lowest in Osun source water and highest in Lagos stored water. There was significant difference between $\mathrm{pH}$ of source and stored water in all the three states Table 1 . The mean temperature values obtained in this study ranged from $15.8 \pm 0.2-25.0 \pm 0.9^{\circ} \mathrm{C}$. There was no significant difference in temperature of source compared with stored water only in Oyo state. The mean turbidity value ranged from 10.4 $\pm 1.0-24.3 \pm 2.6 \mathrm{NTU}$, the lowest was mean stored water in Osun while the highest was mean source water in Oyo state. Turbidity was highly significant in all the states sampled and well above acceptable limits of $<5$ NTU. Total dissolved solids in all the areas were within acceptable limits although there was significant difference between the stored and source waters. There was no significant difference in mean values of DO between stored and source waters but all values were below acceptable limits. Total hardness was within limit in all the samples and there was no significant difference when stored water is compared with sources. 
Table 1: Mean values of the physicochemical parameter of water samples in Oyo, Osun and Lagos State.

\begin{tabular}{|c|c|c|c|c|c|c|c|c|c|c|c|c|c|}
\hline & Oyo State & & & & Osun state & & & & Lagos State & & & & WHO \\
\hline Parameter & Stored (45) & Source (15) & $\mathbf{F}$ & $\mathbf{P}$ & Stored(45) & Source(15) & $\mathbf{F}$ & $\mathbf{P}$ & Stored(45) & Source(15) & $\mathbf{F}$ & $\mathbf{P}$ & limits \\
\hline pH & $6.9 \pm 0.1$ & $6.8 \pm 0.1$ & 0.1 & 0.74 & $6.5 \pm 0.2$ & $6.4 \pm 0.2$ & 0.3 & 0.58 & $6.9 \pm 0.1$ & $6.7 \pm 0.1$ & 2.0 & 0.16 & $6.5-8.5$ \\
\hline TDS (mg/L) & $355.3 \pm 22.4$ & $373.2 \pm 23.2$ & 0.3 & 0.58 & $349.9 \pm 29.2$ & $376.0 \pm 26.0$ & 0.5 & 0.51 & $368.3 \pm 20.9$ & $377.1 \pm 21.2$ & 0.1 & 0.77 & 500 \\
\hline Turbidity(NTU) & $19.4 \pm 2.2$ & $24.3 \pm 2.6$ & 2.1 & 0.30 & $10.4 \pm 1.0$ & $12.7 \pm 1.2$ & 2.6 & 0.16 & $17.0 \pm 2.1$ & $20.8 \pm 2.7$ & 1.3 & 0.26 & $<5$ \\
\hline $\mathrm{BOD}\left(\mathrm{mgO}_{2} / \mathrm{L}\right)$ & $0.8 \pm 0.1$ & $0.8 \pm 0.1$ & 0.0 & 0.90 & $1.6 \pm 0.1$ & $1.2 \pm 0.1$ & 3.8 & 0.05 & $2.7 \pm 0.2$ & $2.7 \pm 0.3$ & 0.0 & 0.90 & - \\
\hline Total hardness(mg/L) & $177.3 \pm 15.7$ & $202.2 \pm 18.1$ & 1.1 & 0.30 & $134.2 \pm 12.1$ & $118.2 \pm 12.0$ & 0.9 & 0.35 & $67.5 \pm 12.2$ & $51.8 \pm 9.5$ & 1.0 & 0.31 & 500 \\
\hline Calcium ion $(\mathrm{mg} / \mathrm{L})$ & $34.2 \pm 3.2$ & $38.9 \pm 3.8$ & 0.9 & 0.35 & $24.5 \pm 2.9$ & $21.9 \pm 3.3$ & 0.6 & 0.56 & $13.1 \pm 2.2$ & $7.6 \pm 1.4$ & 4.5 & 0.03 & - \\
\hline Magnesium ion $(\mathrm{mg} / \mathrm{L})$ & $23.0 \pm 2.3$ & $25.7 \pm 2.5$ & 0.6 & 0.44 & $17.9 \pm 1.7$ & $15.3 \pm 1.3$ & 1.7 & 0.21 & $9.5 \pm 1.3$ & $6.4 \pm 0.8$ & 4.4 & 0.04 & - \\
\hline
\end{tabular}

\subsection{Microbial analysis of source and stored samples}

The mean values of microbiological parameters (HPC, TC, EC, FC and fungi count) obtained for stored water were higher than the mean values of their

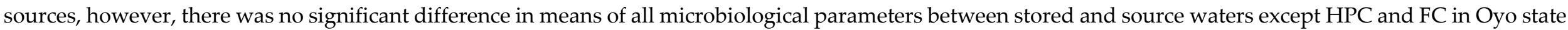

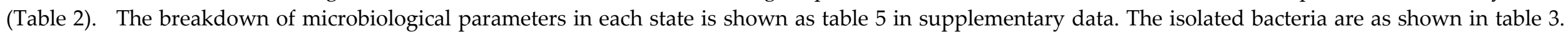

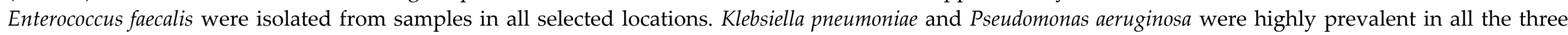

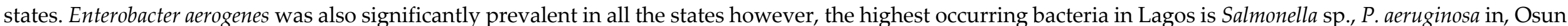

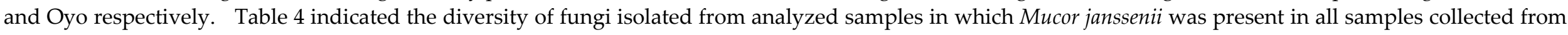

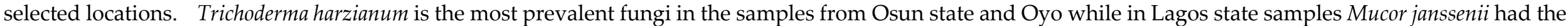
highest prevalence level.

Table 2: Mean values of different microbiological parameters on water samples from Oyo, Osun and Lagos States

States $\rightarrow$

Osun

Lagos

Oyo

WHO Limits 


\begin{tabular}{|c|c|c|c|c|c|c|c|c|c|c|c|c|c|c|}
\hline Points & $\begin{array}{l}\text { of Collection (No. of } \\
\text { Samples) } \rightarrow\end{array}$ & 离 & 总 & 工 & $a$ & 离 & 总 & E & $a$ & 离总 & 营 & {$[x$} & $a$ & \\
\hline \multirow{5}{*}{ 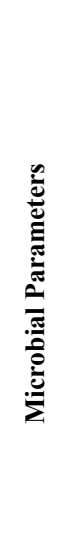 } & $\begin{array}{l}\text { Heterotrophic Plate } \\
\text { Count (cfu/100ml) }\end{array}$ & $140.9 \pm 13.4$ & $82.0 \pm 10.7$ & 11.8 & 0.00 & $\begin{array}{l}112.3 \pm 1 \\
3.3\end{array}$ & $77.4 \pm 7.9$ & 5.1 & 0.03 & $152.6 \pm 15.2$ & $80.9 \pm 7.6$ & 17.8 & 0.75 & $<10$ \\
\hline & $\begin{array}{l}\text { Fecal Coliform Count } \\
(\mathrm{cfu} / 100 \mathrm{ml}))\end{array}$ & $42.0 \pm 7.0$ & $9.6 \pm 2.5$ & 18.8 & 0.00 & $12.8 \pm 6.8$ & $1.4 \pm 0.5$ & 2.8 & 0.10 & $14.48 \pm 6.07$ & $10.0 \pm 4.2$ & 0.4 & 0.55 & 0 \\
\hline & $\begin{array}{l}\text { Enterococci Count } \\
\text { (cfu/100ml) }\end{array}$ & $59.1 \pm 8.8$ & $24.9 \pm 4.7$ & 11.8 & 0.00 & $26.3 \pm 7.9$ & $16.7 \pm 5.2$ & 1.0 & 0.32 & $49.28 \pm 11.34$ & $12.0 \pm 3.3$ & 1.0 & 0.00 & $\mathbf{0}$ \\
\hline & $\begin{array}{l}\text { Total Coliform Count } \\
\text { (cfu/100ml) }\end{array}$ & $46.2 \pm 7.1$ & $12.3 \pm 3.3$ & 18.9 & 0.00 & $\begin{array}{l}72.0 \pm 15 . \\
5\end{array}$ & $49.9 \pm 10.5$ & 1.4 & 0.24 & $28.40 \pm 9.70$ & $11.3 \pm 4.7$ & 2.5 & 0.12 & no limit given \\
\hline & $\begin{array}{l}\text { Fungal Count } \\
\text { (cfu/100ml) }\end{array}$ & $109.6 \pm 12.5$ & $46.0 \pm 6.0$ & 21.0 & 0.00 & $93.6 \pm 8.4$ & $111.5 \pm 7.1$ & 2.7 & 0.11 & $99.58 \pm 9.22$ & $55.9 \pm 3.4$ & 19.8 & 0.00 & no limit given \\
\hline
\end{tabular}


Table 3: Bacteria Isolated from Sampled Areas.

\section{Isolated Bacteria}

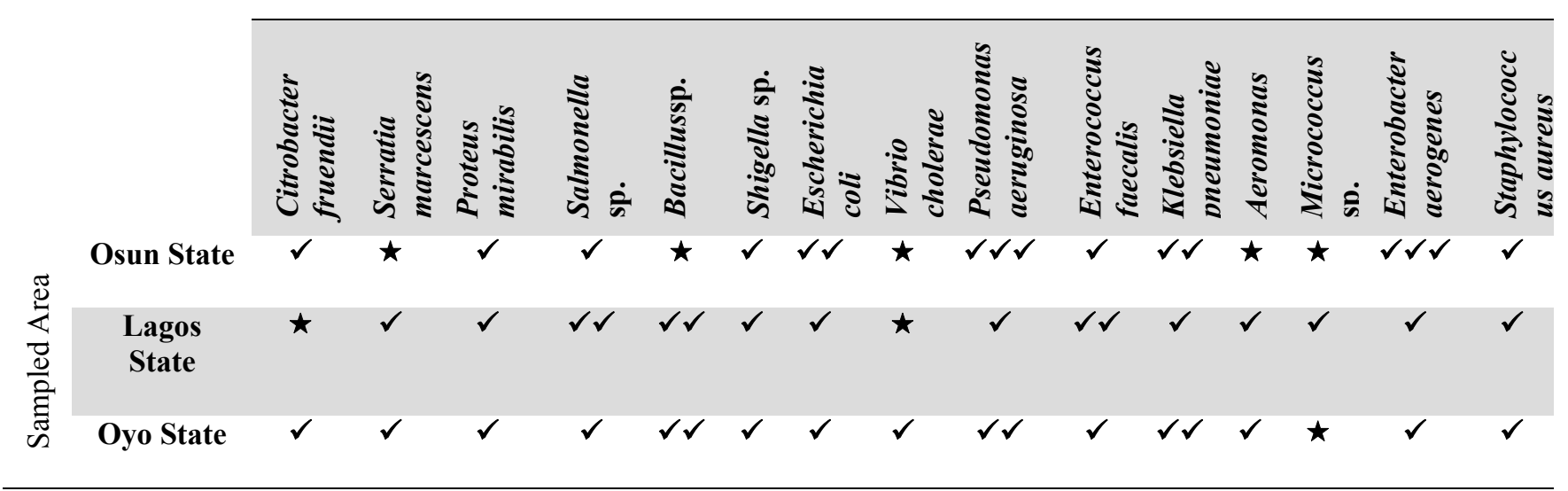

KEYS: $(\star)$ No Isolate, $(\checkmark)$ Low prevalence, $(\checkmark \checkmark)$ Moderate prevalence level, $(\checkmark \checkmark \checkmark)$ High prevalence level

Table 4: Fungi Isolated from Sampled Areas.

Isolated Fungi

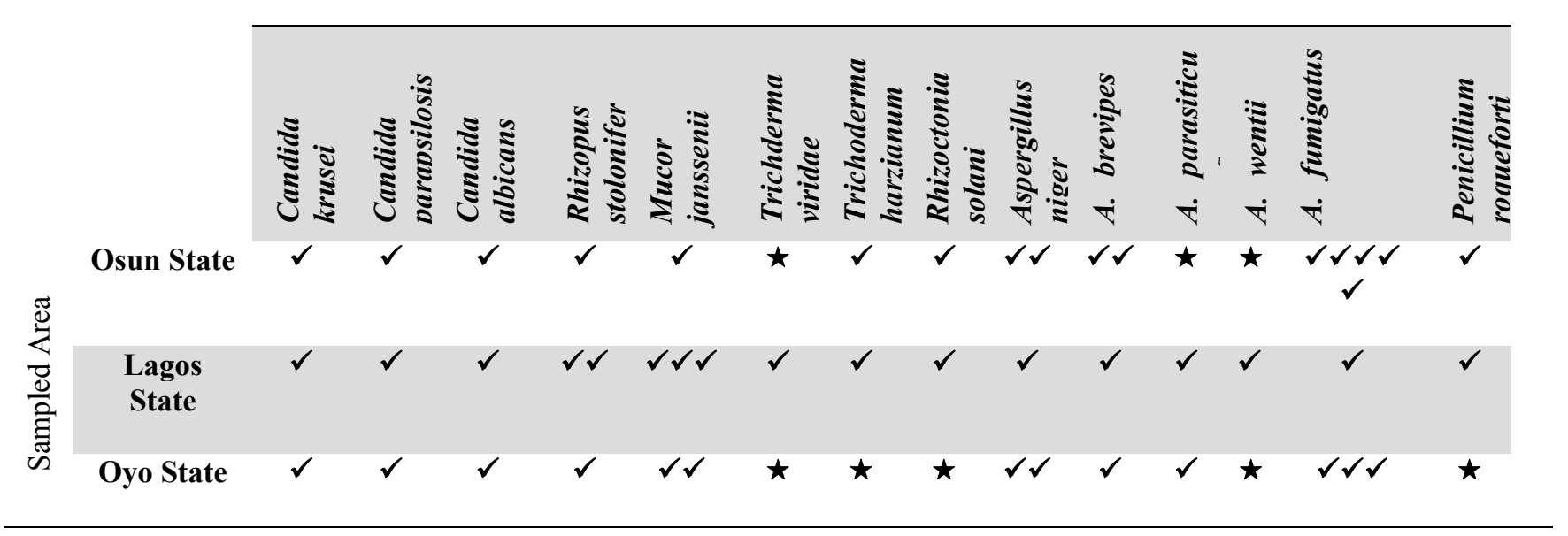

KEYS: $(\star)$ No Isolate, $(\checkmark)$ Low prevalence, $(\checkmark \checkmark)$ Moderate prevalence level, $(\checkmark \checkmark \checkmark)$ High prevalence level, $(\checkmark \checkmark \checkmark \checkmark \checkmark)$ Very high prevalence level 


\section{Discussion}

The survival of microorganisms in waters is highly influenced by many environmental factors such as temperature, salinity, $\mathrm{pH}$, turbidity and supply of organic matter as nutrients [37]. The measure of concentration of hydrogen and hydroxyl ion is an important index of acidity or alkalinity [38]. The average $\mathrm{pH}$ value of samples (source and stored) from the study areas fell within standard (6.5- 8.5) stipulated international limits. The increase in $\mathrm{pH}$ values of the stored water above sources could be as a result of the activities of the resident flora and or their death which results in the release of inorganic substances such as ammonia [39]. Changes in $\mathrm{pH}$ are known to be a resultant of processes such as photosynthesis, respiration, temperature exposure to air, disposal of industrial wastes, geology and mineral content of a catchment area, acid mine drainage, agricultural runoff, carbon dioxide concentration in the atmosphere, and accumulation and decomposition of organic detritus in the water producing weak carbonic acids that impact on $\mathrm{pH}$ [40]. Furthermore, the increase in the mean values of the DO (stored water) might be as a result of exposure of the containers to air during storage [41]. Dissolved oxygen (DO) serves as an indicator of the biological health of a water body. Dissolve oxygen levels can fluctuate throughout the day and are affected by changes in water temperature, the concentration of organic materials (i.e. industrial or municipal wastes can increase the concentration of organic matter) [42]. Water turbidity is very important because high turbidity is often associated with higher level of disease causing microorganism such as bacteria and other parasites [43]. Also, turbidity levels are dependent on the amount of suspended particles present in the water. Suspended particles act as a substrate for microorganisms in the water, thus promoting growth of the microorganism populations. The increase in mean values of the turbidity (source water) is an indication of pollution which enhances increase in number of disease causing microorganisms. Water with excess TDS can reduce water clarity, hereby harbouring microorganisms of health importance [44]. High mean values of TDS (source water) might be as a result of pollution which also enhances the growth of microorganism. Chemical contaminant can pose public health problem after prolonged exposure in particular those that can bio-accumulate.

High mean HPC, TC and FC values that was observed in stored water might be as a result of contamination from their untidy or unclean storage facilities, interaction of the little children with the water, insertion of dirty container to collect or remove water from the storage container, uncovered containers which are prone to environmental conditions such as dust and dirt [45]. Furthermore, in EC count, the high values observed in stored water indicated contamination which might be as a result of low level of sanitation facilitated by hands during defecation or other activities, using of unclean materials in getting water from the storage etc. Pickering et al. [46] reported a positive correlation between enterococci on hands and enterococci in stored drinking water in households in peri-urban Dar es Salaam. Pickering et al. [47] suggested that post-collection contamination of stored waters in areas with low levels of sanitation could be facilitated by hands contaminated during defecation or other activities. The isolation of these potential pathogenic organisms such as E. coli, K. pneumonia, P. aeruginosa, E. aerogenes, Salmonella sp., Aspergillus sp, Mucor sp, Rhizopus sp and Candida sp (Table 3\&4) from analyzed samples in this study is an indication of poor hygiene and sanitation on the part of the users and pose health risks. The presence of E. coli and opportunistic pathogens in some of the samples indicated recent faecal contamination and is of major health importance. Similar studies were carried out by Schets et al. [48] who analyzed quality of drinking water from private water supplies in Netherland, the result showed that $10.9 \%$ samples were contaminated due to faecal organisms such as E. coli and Enterococcus species. 
Filamentous fungi (mainly of the genera Aspergillus, Mucor and Rhizopus (Table 4) are typically more prevalent than yeast and yeast-like fungi. This high prevalence level is in agreement with Göttlich et al. [49] and Patterson et al. [50]. Aspergillus sp was observed dominating among the fungi isolated from the samples. Presence of some of the fungi may put consumers of such water at risk of infections such as aspergillosis, hypersensitivity pneumonitis, extrinsic allergic alveolitis, and opportunistic infections such as parlous disease caused by Rhizopus sp. [51-53].

\section{Conclusions}

Water of poor quality is a threat to the health and wellbeing of the populace. The study examined the physical, chemical and microbiological parameters of household stored domestic water and their corresponding sources. Improper handling of both source and stored water were observed and this is due to poor hygiene and sanitation level of the handlers.Therefore, it is recommended that both stored and source water should be from good quality sources such as adequately treated municipal water supply, deep boreholes andstorage should be in clean covered containers preferably with tap. Also, the periodic cleaning and disinfection of the storage facilities is highly desirable in order to prevent contamination.

Supplementary Materials: The following are available online at www.mdpi.com/link, Table 5: Mean values of different microbiological parameters on samples by the selected LGA in Oyo, Osun and Lagos State; Figure S1:Gbaro spring water Olode (Ife South); Figure S2: Alum water Olode (Ife South).

Acknowledgments:We are grateful to the Heads of department of Microbiology, Obafemi Awolowo University, Ile-Ife and Biological Sciences, Yaba College of Technology (YCT), Lagos, Nigeria where laboratory analysis were conducted. We are also grateful to members of the local government communities who provided information in this study. The support received from Dr. Adetoro of Chemistry department YCT would not go unmentioned.

Author Contributions: MAB conceived of the study, participated in the design and coordination of the study, participated in field work and preparation of the manuscript. KOA participated in field and laboratory work and drafting of the manuscript. SAA performed the experiments, analyzed the dataand also drafted the manuscript. EOP was involved in some aspect of sampling, laboratory coordination and physicochemical analysis. AIO assisted with the concept and design of the study, provided technical advice and revised manuscript. All authors read and approved the final manuscript.

Conflicts of Interest:The authors declare that they have no conflicts of interests on this work.

\section{References}

1. UNICEF. World Water Day: 4,000 children die each day from a lack of safe water, 2005. Available at http://www.unicef.org/wash/index_25637.html.Accessed 12 Dec. 2016.

2. Onabolu, B.; Jimoh, O.D.; Igboro, S.B.; Sridhar, M.K.C.; Onyilo, G.; Gege, A.; Ilya, R. "Source to point of use drinking water changes and knowledge, attitude and practices in Katsina State, Northern Nigeria", Phy. Chem. Earth,2011; Parts A/B/C, 36 (15): 1189-1196.

3. Wateraid.org. WaterAid - water charity news, 2016. Available online: http://www.wateraid.org/ng\#sthash.qBgz2PhY.dpuf (Accessed 20 Dec. 2016).

4. Karavoltsosa, S.; Sakellaria, A.; Mihopoulosb, N.; Dassenakisa, M.; Scoullosa, M.J. Evaluation of the quality of drinking water in regions of Greece. Desalination, 2008; 224: 317-329.

5. Manish, U.; Bed, L.; Om Prakas, P. Degradation of water quality due to heavy pollution in industrial area of Korba, Chhattisgarh. Rec. Res. in Sci. Technol, 2013; 5 (5): 37-39. 
6. U.S. Environmental Protection Agency (USEPA). Protecting water quality from agricultural runoff. Available online: http:// www. epa.gov. /owow / nps/Ag Runoff Fact Sheet.pdf). Fact sheet No.EPA-841-F-05-001. March 2005. (Accessed 6 Nov. 2016).

7. Manish, U.; Sudhir, P. Analysis of surface and industrial waste water in Sipat industrial area in Bilaspur district, Chhattisgarh, India. Int. J. Pharm., 2016; 6 (1): 74-77.

8. Schueler, T.R. Microbes and urban watershed: concentration, source and pathway. 2000; Reprinted in The Practice of Watershed Protection. Available online: http//www.cwp.org/resource_library/center_docs. (Accessed 7 Nov. 2016).

9. World Health Organization (WHO). Guidelines for drinking-water quality. 2011. Available online: http://www.who.int/water sanitation health/publications/2011/dwq_guidelines/en/ (Accessed 5 Nov. 2016).

10. Hogan, C. M. Water pollution. Encyclopedia of earth. National council on science and the environment, Washington, DC. 2010. Available online: http//www.oearth.org/article/Water_pollution (Accessed 20 Nov. 2016).

11. U.S. Environmental Protection Agency (EPA). Report to congress: Impacts and Control of CSOs and SSOs. August, 2004. Document No.EPA-833-R-04-001. Available at: (http://cfpub.epa.gov/npdes/cso/cpolicy report 2004.cfm). (Accessed 6 Nov. 2016).

12. WHO/UNICEF. Joint Monitoring Programme for Water Supply and Sanitation. Progress on drinking water and sanitation: 2014 Update. New York,

13. World Health Organization (WHO). Pathogenic Mycobacteria in Water: A Guide to Public Health Consequences, Monitoring and Management, Pedley, S., Batram, J., Rees, G., Dufuor, A., Cotruvo, J., Eds., IWA Publishing: London, UK. 2004.

14. Roohul-Amin, S.A.; Jabar Z.K. Microbial analysis of drinking water distribution in New Urban Peshawar. Curr. Res. J. Biol. Sci., 2012; 4(6): 731-737.

15. Xu, H.; Yang, L.; Zhao, G.; Jiao, J.; Yin, S.; Liu, Z. Anthropogenic Impact on Surface Water Quality in Taihu Lake Region, China. Pedosphere, 2009, 19(6), 765-778.

16. Azrina, M.Z.; Yap, C.K.; Rahim-Ismail, A.; Ismail, A.; Tan, S.G. Anthropogenic impacts on the distribution and biodiversity of benthic macroinvertebrates and water quality of the Langat River, Peninsular Malaysia. Ecotoxicol. Env. Safety, 2006; 64(3), 337-347.

17. Annalakshmi, G.; Amsath, A. Nutrient status of Arasalar river, a tributary of Cauvery river at Tanjore district of Tamilnadu, India. Int. J. Plant Animal Env. Sci., 2012, 2, 214-222.

18. Okonko, I.O.; Ogunnusi, T.A.; Adejoye, O.D.; Shittu, O.B. Microbiological and Physicochemical Analysis of Different Water Samples Used for Domestic Purposes in Abeokuta, Ogun State and Ojota, Lagos State, Nigeria. Afr. J. Biotech., 2008a; 7(5): 617-621.

19. Okonko, I.O.; Ogunjobi, A.A.; Adejoye, O.D.; Ogunnusi, T.A.; Olasogba, M.C. Comparative studies and Microbial risk assessment of different water samples used for processing frozen sea-foods in Ijora-Olopa, Lagos State, Nigeria. Afr. J. Biotech., 2008b; 7(16): 2902-2929.

20. Patil, V.T.; Patil, P.R. Physicochemical Analysis of Selected Groundwater Samples of Amalner Town in Jalgaon District, Maharashtra, India. Int. J. Adv. Earth Sci. Eng. 2010; 7 (1): 111-116.

21. Grisey, E.; Belle, E.; Dat, J.; Mudry, J.; Aleya, L. Survival of pathogenic and indicator organisms in groundwater and landfill leachate through coupling bacterial enumeration with tracer tests. Desalination, 2010; 261(1-2):162-168.

22. Julie, D.; Solen, L.; Antoine, V.; Jaufrey, C.; Annick, D.; Dominique, H.H. Ecology of pathogenic and non-pathogenic Vibrio parahaemolyticus on the French Atlantic coast. Effects of temperature, salinity, turbidity and chlorophyll. Environ. Microbiol., 2010; 12: 929-937.

23. Eniola, K.I.T.; Olayemi, A.B.; Adegoke, A.; Abolade, O.O.; Kayode-Isota, T.M. Effect of storage on the bacteriological quality of well water. Afr. J. Cli. Exp. Microbiol., 2006; 2: 27-32.

24. Eniola, K.I.T.; Obafemi, D.Y.; Awe, S.F.; Yusuf, I.I.; Falaiye, O.A. Effect of container and storage conditions on the bacteriological quality of borehole water in Nigeria. J. Microbiol., 2007; 21: 1578-1585.

25. Wright, J.; Gundry, S.; Conroy, R. Household drinking water in developing countries: a systematic review of microbiological contamination between source and point-of-use. Trop. Med. Health., 2004; 9 (1): 106-117.

26. Trevett, A.F.; Carter, R.C.; Tyrrel, S.F. Mechanisms leading to post-supply water quality deterioration in rural Honduran communities. Int. J. Hyg. Environ. Health, 2005; 208 (3), 153-161. 
27. Ravichandran, P.; Subha, K.; Sugumaran, P.; Unnamalai, N. Effect of Storage Containers on Coliforms in Household Drinking Water. Int. J. Microbiol. App. Sci. 2016; 5(1): 461-477.

28. Jensen, P.P.; Ensink, J.H.J.; Jayasinghe, G.; Van der Hoek, W.; Cairncross, S.; Dalsgaard, A. Domestic transmission routes of pathogens: the problem of in-house contamination of drinking water during storage in developing countries. Trop. Med. Health, 2002; 7 (7): 604-609.

29. Onigbogi, O.; Ogunyemi. O. Effect of Storage Containers on Quality of Household Drinking Water in Urban Communities in Ibadan, Nigeria. Int. J. Pub. Health. Sci. 2014; 3(4): 253-258.

30. WHO/UNICEF. Progress on Drinking Water and Sanitation: 2012; Update. World Health Organization, Geneva and United Nations Children's Fund, New York.Available online: https://www.unicef.org/media/files/JMPreport2012.pdf (Accessed 5 Nov. 2016).

31. Benjamin, A.P.; Brown, R. Encyclopaedia of food Science and Nutrition, $2^{\text {nd }}$ ed. Vol. 10. United Kingdom: Academic Press. 2003.

32. APHA, AWWA and WEF. Standard methods for the examination of water and wastewater. $21^{\text {st }}$ ed. American Public Health Association, American Water Works Association and Water Environment Federation, Washington, D.C. 2005.

33. Food and Agricultural Organization (FAO). Chemical analysis manual for food and water, 5th ed. FAO ROME, 1997; 1: 20-26.

34. Ademoroti, C.M.A. Standard Methods for Water and Effluent Analysis. Foludex Press Ltd, Ibadan, $1996 ; 182$.

35. Buchanan, R.E.; Gibbons, N.E. Bergey's Manual of Determinative Bacteriology $8^{\text {th }}$ edition. The Williams and Wilkins Company, Baltimore. 1994.

36. Watanabe, T. Pictorial Atlas of Soil and Seed Fungi. Kluwer Academic Publishers. 2002.

37. Pommepuy, M.; Guillaud, J.F.; Dupray, E.; Derrien, A.; Le Guyader, F.; Cormier, M. Enteric bacteria survival factors. Wat. Sci. Tech.; 1992, 25 (12): 93-103.

38. World Health Organization (WHO). Guidelines for Drinking water Quality, Incorporating 1st and $2^{\text {nd }}$ Addenda, 2008; Vol. 1, Recommendations, $3^{\text {rd }}$ ed.; WHO: Geneva, Switzerland.

39. Rogbesan, A.A.; Eniola, K.I.T.; Olayemi, A.B. Bacteriological Examination of some Boreholes within University of Ilorin (PS). Nig. J. Pure and Applied Sci., 2002; 17: 1223-1226.

40. Sibanda, T.; Chigor, V.N.; Koba, S.; Obi, C.L.; Okoh, A.I. Characterisation of the physicochemical qualities of a typical rural-based river: ecological and public health implications. Int. J. Env. Sci Technol, 2014, 11, 1771- 1780 .

41. Oluyemi, E.A.; Adekunle, A.S.; Adenuga, A.A.; Makinde, W.O. Physico chemical properties and heavy metal content of water sources in Ife North Local Government Area of Osun State, Nigeria. Afr. J. Environ Sci. Tech., 2010; 4 (10): 691-697.

42. U. S. Environmental Protection Agency (USEPA). Volunteer Stream Monitoring: A Methods Manual, USEPA 841-B-97-003. U.S. Environmental Protection Agency. Methods for volunteer monitoring of streams. 1997. Available online: http:// www.usepa.gov/owow/monitoring/ volunteer. (Accessed 5 Nov, 2016).

43. Shittu, O.B.; Olaitan, J.O.; Amusa, T.S. Physico-Chemical and Bacteriological Analysis of Water Used for Drinking and Swimming Purpose. Afr. J. Bio. Res., 2008; 11: 285-290.

44. U. S. Environmental Protection Agency (EPA). “Volunteer Lake Monitoring: A Methods Manual,” EPA 440/4-91-002, Office of Water US Environ-mental Protection Agency, Washington D.C. 1999. pp 65Available online https://archive.epa.gov/water/archive/web/html/lakevm.html (Accessed 5 Nov, 2016).

45. Moore, A.C.; Herwaldt, B.L.; Craun, G.F.; Calderon, A.K. Waterborne disease in the United States, 1991 and 1992. J Am Water Works Assoc.1994, 86:87-99.

46. Pickering, A.J.; Davis, J.; Walters. S.P.; Horak, H.M.; Keymer, D.P.; Mushi, D.; Rachelle S.; Joshua, S.C.; Jesse, L.; Annalise, B.; Kristen, R.; Alenxandra, B.B. Hands, water, and health: fecal contamination in Tanzanian communities with improved, non-networked water supplies. Environ. Sci. Technol., 2010; 44 (9): 3267-3272.

47. Pickering, A.J.; Julian, T.R.; Mamuya, S.; Boehm, A.B.; Davis, J. Hand fecal contamination among Tanzanian mothers varies temporally and following household activities. Trop. Med. Intern. Health, 2011; 16 (2): 233-239.

48. Schets, F.M.; During, M.; Italiaander, R.; Heijnen, L.; Rutjes, S.A.; van der Zwaluw, W.K.; de RodaHusman, A,M.Escherichia coli O157:H7 in drinking water from private water supplies in the Netherlands Water Res., 2005; 39: 4485-4493. 
49. Göttlich, E.; van der Lubbe, W.; Lange, B.; Fiedler, S.; Melchert, I.; Reifenrath, M.; Flemming, H.C.; de Hoog, S. Fungal flora in groundwater-derived public drinking water. Int. J Hyg Env Health, 2002, 205 : 269-279.

50. Paterson, R.R.M.; Hageskal, G.; Skaar, I.; Lima, N. Occurrence, problems, analysis and removal of filamentous fungi in drinking water. In Fungicides: Chemistry, Environmental Impacts and Health Effects, De Costa, P. and Bezerra, P. (eds.), Nova Science Publishers, Inc. 2009.

51. Anaissie, E.J.; Stratton, S.L.; Dignani, M.C.; Summerbell, R.C.; Rex, J.H. ; Monson, T. P.; Spencer, T.; Kasai, M.; Francesconi, A.; Walsh, T. J. Pathogenic Aspergillus species recovered from a hospital water system: a 3-year prospective study. Clin. Infect. Dis., 2002; 34: 780-789.

52. De Rosa, F.G.; Garazzino, S.; Pasero, D.; Di Perri, G.; Ranieri, V.M. Invasive candidiasis and candidemia: new guidelines. Minerva Anestesiologica, 2009; 75 (7-8): 453-458.

53. Hageskal, G.; Lima, N.; Skaar, I. The study of fungi in drinking water. Mycol. Res., 2009; 113: 165-172.

(C) 2017 by the authors. Licensee Preprints, Basel, Switzerland. This article is an open access article distributed under the terms and conditions of the Creative Commons by Attribution (CC-BY) license (http://creativecommons.org/licenses/by/4.0/). 